\title{
ANALISIS KONDISI SOSIAL EKONOMI MASYARAKAT TRANSMIGRAN ETNIK BALI DI DESAWAPAE JAYA KECAMATAN TIWORO TENGAH KABUPATEN MUNA BARAT
}

\begin{abstract}
Suwardin 1
Abstrak :Penelitian ini bertujuan untuk menganalisis kondisi sosial ekonomi masyarakat transmigran etnik Bali di Desa Wapae Jaya Kecamatan Tiworo Tengah Kabupaten Muna Barat. Penulisan hasil penelitian disajikan secara deskriptif untuk memperoleh gambaran mengenai kondisi sosial ekonomi masyarakat transmigran etnik Bali di Desa Wapae Jaya Kecamatan Tiworo Tengah Kabupaten Muna Barat.Teknik pengumpulan data menggunakan metode observasi, wawancara, angket dan dokumentasi. Hasil penelitian dilapangan menunjukankondisi sosial ekonomi masyarakat transmigran etnik Bali di Desa Wapae Jaya Kecamatan Tiworo Tengah Kabupaten Muna Barat untuk pendidikan tergolong rendah. Hal ini dapat dilihat dari pendidikan responden dimana dari 420 responden sebanyak 256 responden atau sebesar $62,95 \%$ hanya menamatkan pendidikan formalnya pada tingkat SD, kumudian dilihat dari kondisi kesehatannya dapat dikategorikan sedang dimana dapat dilihat kondisi kesehatan responden dalam 6 bulan terakhir dimana hanya terdapat $10 \%$ yang kadang-kadang terserang penyakit, kemudian dilihat dari kondisi perumahan dapat dikategorikan baik, dimana responden sudah memiliki rumah sendiri dan didukung jugakondisi fisik bangunan,sumber penerangan, sember air bersih yang digunakan dan kepemilikan MCK. Kemudian dari segi ekonomi tergolong sedang dimana pendapatan rata-rata responden per bulan berkisarRp2.500.000 sampai Rp3.500.000.Kesimpulanpenelitian ini sebagai berikut: rendahnya tingkat pendidikan responden karena kurangnya pemehaman tentang pendidikan dan kurangnya motivasi dari orang tua.
\end{abstract}

\section{Kata Kunci : Masyarakat Transmigran, Etnik Bali danKondisiSosialEkonomi}

\section{PENDAHULUAN}

Indonesia adalah Negara berkembang yang berbentuk kepulauan (archipelago), dengan \pm 13.667 pulau besar maupun kecil, dimana \pm 3.000 pulau diantaranya diperkirakan telah didiami penduduk dengan penyebaran yang tidak merata. Ketidak merataan penyebaran penduduk tersebut merupakan salah satu faktor penghambat pembangunan nasionalUntuk mengantisipasi masalah tersebut maka pemerintah mengeluarkan berbagai kebijakan termasuk program transmigran sebagai upaya antisipatif terhadap ledakan penduduk yang tidak merata antara daerah yang satu dengan yang lainnya.

Tujuan transmigran bukan untuk hanya mengurangi kepadatan penduduk di pulau Jawa dan Bali, tetapi seperti yang termaksud dalam Undang- Undang Nomor 15 Tahun 1887 tentang tujuan penyelenggaraan transmigran adalah sebagai upaya pendayagunaan tenaga kerja, penyebaran penduduk secara merata, diarahkan untuk memperbaiki mutu kehidupan, meningkatkan pendayagunaan sumber daya alam, memperluas lapangan kerja, kesempatan kerja, serta memperkokoh persatuan dan kesatuan bangsa. (Departemen Transmigrasi dan PPH, $1988: 5$ ).

Sebagai perwujudan program transmigran, dimana kabupaten Muna Barat yang merupakan daerah pemekaran dari Kabupaten Muna merupakan salah satu Wilayah yang menjadi daerah transmigran. Kehadiran transmigran Di pulau muna akan Mempertemukan beberapa kelompok etnik yang akan membuahkan dua 
alternative, baik yang bersifat positif maupun yang bersifat negatif.

Desa Wapae Jaya merupakan salah satu Desa yang berada dalam wilayah Kecamatan Tiworo Tengah Kabupaten Muna Barat dimana di Desa tersebut merupakan daerah transmigran etnik Bali. Sebagian besar masyarakat transmigran etnik Bali yang ada di Desa tersebut bermata pencaharian pertanian. Pada umumnya masyarakat transmigran etnik Bali yang ada di Desa Wapae Jaya hidup secara berkelompok dan mereka menggantungkan hidupnya dengan hasil pertanian. Meskipun kondisi lingkungan alam yang selalu berubah- ubah dan peralatan yang digunakan juga masih sangat sederhana tetapi hasil pertanian masyarakat transmigran etnik Bali di Desa Wapae Jaya selalu mendapatkan hasil pertanian yang maksimal.

selain sektor pertanian sebagain masyarakat transmigran etnik Bali yang ada di Desa Wapae Jaya juga memiliki mata pencaharian seperti montir, peternak, dan Pegawai Negeri Sipil (PNS).

Berdasarkan hasil pengamatan (observasi) dilapangan tingkat kehidupan sosial ekonomi mayarakat transmigran etnik Bali sudah mengalami peningkatan, Hal ini ditandai dengan kondisi rumah hunian mereka dimana sebagian atau lebih banyak sudah tidak menggunakan rumah panggung atau sudah memiliki rumah permanen dan bahkan kebanyakan para orang tua sudah menyadari arti pentingnya anakanak mereka untuk memperoleh pendidikan.

Berdasarkan uraian diatas dimana menunjukan bahwa masyarakat transmigran etnik Bali yang ada di Desa Wapae Jaya Kecamatan Tiworo Tengah Kabupaten Muna Barat sudah mengalami peningkatan dimana dapat dilihat dari bentuk rumah, pendidikan, kesehatan dan juga pendapatan, sehingga penulis tertarik untuk mengkaji kondisi sosial ekonomi masyarakat transmigran etnik Bali dengan judul "Analisis Kondisi Sosial Ekonomi Masyarakat Transmigran Etnik Bali di Desa Wapae Jaya Kecamatan Tiworo Tengah Kabupaten Muna Barat".

Analisis menurut Supranto (1998 : 117) adalah mempunyai dua pengertian yaitu :a. Mengurai/memecah sesutau menjadi bagian-bagian atau komponen-komponen lebih kecil, sesuai dengan tujuan analisis supaya; 1) Dapat mengetahui komponen yang mempunyai sifat yang menonjol atau mempunyai nilai ekstrim; 2) Dapat melakukan perbandingan antara komponen dengan mempunyai nilai ekstrim,3) Dapat melakukan perbandingan antara komponen dengan keseluruhan dengan menggunakan nilai proporsi keseluruhan. b.Memperkirakan atau memperhitungkan besarnya pengaruh secara kuantitatif dari perubahan suatu (beberapa) kejadian lainnya dapat dinyatakan dengan perubahan nilai variable hasil perhitungan yang dapat digunakan untuk dasar evaluasi dari suatu kebijakan.

Konsep Masyarakat, Istilah masyarakat berasal dari bahasa arab yaitu syarakat, yang berarti ikut serta, berpartisipasi dan dalam bahasa Inggris kita kenal dengan "society" dan "community" yang kedua-duanya diterjemahkan sebagai masyarakat.

Ralph Linton dalam Soerjono Sukanto (1982:35) mengatakan bahwa masyarakat adalah pergaulan hidup yang akrab antara manusia yang dipersatukan dengan cara-cara tertentu.

Masyarakat merupakan suatu kumpulan manusia yang senantiasa mengadakan pergaulan secara dinamis antara satu dengan yang lainnya. Adanya pergaulan ini karena adanya bentuk-bentuk aturan hidup yang bukan disebabkan oleh manusia sebagai perseorangan melainkan oleh unsur-unsur kekuatan lain dengan lingkungan sosial yang merupakan kesatuan yang bersifat 
kontinyu dan terikat oleh suatu rasa identitas bersama. (Seorjono Sukanto:50).

Dalam arti khusus masyarakat disebut juga kesatuan sosial yang mempunyai ikatan kasih sayang yang erat, mirip jiwa manusia yang dapat diketahui, pertama melalui perbuatan dan kelakuannya sebagai penjelasan yang lahir, kedua melalui pergaulan batin dalam roh manusia, perorangan, sendiri, bahkan memperoleh superioritas meraskan sebagai suatu yang tinggi nilainya. Sesuatu yang tinggi nilainya dari pada jumlah bagian-bagian sesuatu yang kokoh, kuat, sesuatu perwujudan pribadi didalam bukan diluar bahkan diatas kita.

Masyarakat dilihat dari
kekuatan impersonal yang mempengaruhi, menyokong dan juga menentukan tingka lakuh anggotaanggotanya. Pandangan ini selaras dengan pandangan Durkheim (dalam Sulaeman B. Taneko : 34) yang menyatakan bahwa masyarakat merupakan suatu kenyataan obyektif secara mandiri bebas dari individuindividu yang merupakan anggotaanggotanya. Menurut kita harus mencari pengertian tentang kehidupan sosial didalam lingkungan masyarakat. Menurutnya masyarakat bukan saja merupakan suatu penjumlahan individu semata-mata, tetapi merupakan suatu sistem yang dibentuk dari hubungan antara mereka sehingga menimbulkan suatu realita tertentu yang mempunyai cirri-ciri tersendiri.Menurut Konjaraningrat (1990), masyarakat adalah sekelompok manusia yang hidup bersama yang didalamnya ada ikatanikatan nilai dan norma serta aturan yang menjadi patokan dalam berinteraksi, hubungan antara mereka yang menempati wilayah yang sama.

KonsepTransmigrasi, Masalah transmigrasi bukan masalah baru dalam perkembangan bangsa Indonesia. Hal ini sudah menjadi program pemerintah pusat dalam menyediakan bantuan kepada para transmigrasi berapa biaya pangangkutan, perlengkapan tidur dan sebagainya. Demikian halnya transmigrasi sektoral yang diselenggarakan secara bersama antara pemerintah daerah asal dan pemerintah daerah penetapan. Transmigrasi ini sebagaimana halnya dengan transmigrasi umum yang membedakan dalam hal pembiayaan (Depdikbud, 1977/1988 : 20). Sementara itu transmigrasi lokal merupakan bentuk pemindahan penduduk dalam suatu wilayah administratif yang sama yaitu pengurusan dan pembiayaan seluruhnya diatur oleh daerah pemerintah sendiri.

Transmigrasi dan Kehidupan Masyarakat, Didalam kehidupan masyarakat di daerah tranmigrasi sebagai tmapat berkumpul dan bertemu dengan berbagai kelompak etnik yang setiap anggotanya nakan memainkan peran dalam upaya mengungkapkan akan berinteraksi.

Oleh karena itu, peran yang dilakukan itu berupa tindakan yang mewakili keberadaannya, baik sebagai indivudu maupun dalam suatu komunitas sebagai kelompak masyarakat.Wujud di dalam interaksi sosial atau kelompok dalam kehidupan bermasyarakat tidak lepas dari dua factor yaitu : Pertama, sikap dan system nilai budaya. Kedua, nilai budaya akan mempengaruhi pola tindakan manusia baik secara langsung maupu melalui pola-pola berpikir seseorang atau masyarakat (Chodibah Budi Raharjo, 1984 : 145). Faktor dari wujud interaksi sosial masyarakata dapat berlangsung dalam siklus kehidupan masyarakat.

Menurut Konjaraningrat siklus kehidupan yang mewujudkan suatu interaksi sosial adalah sikap akan terwujud pada pola-pola tindakan yang berubah pada system nilai budaya. Nilai budaya itu akan terwujud pada normanorma, kemudian mempengaruhi pola pikir, sehingga menjdi image 
masyarakat (Chodibah Budi Raharja, 1984 : 146), siklus wujud interaksi tersebut kembali ditegaskan oleh Konjaraningrat bahwa system nilai budaya adalah suatu rangkayan dari warga suatu masyarakat, mengenai apa yang harus dianggap penting dan berharga dan apa yang dianggap remeh dan tidak berharga dalam hidup.

Sosial Ekonomi,Kehidupan sosial diartikan sebagai tatanam kehidupan bersama individu dalam suatu komunitas dan melakukan berbagai aktifitas kehidupan untuk memenuhi kebutuhan keluarga atau rumah tangga.

Untuk memenuhi kebutuhan sosial secara jelas sebenarnya adalah merupakan bagian dari kualitas hidup masyarakat itu sendiri, dan untuk mengetahui terlebih dahulu diketahui indikatornya antara lain pendidikan, perumahan, kesehatan, pendapatan, lingkungan, stabilitas nasional dan lapangan kerja.Gani (1984 : 23), mengatakan bahwa kualitas manusia dapat dilihat dari keadaan yang bersifat fisik. Dia membedakan kualitas manusia dan kualitas hidup, dimana kualitas manusia dengan sifatnya perorangan yang berkaitan langsung dengan sifat yang melekat pada diri seseorang.

$$
\text { Keadaan Kondisi Sosial }
$$

Ekonomi,Secara umum dapat dikatakan bahwa kondisi sosial ekonomi adalah sama pengertiannya dengan membahas seluruh kehidupan aspek masyarakat yang bersangkutan. Hal ini mengingat adanya kenyataan hidup seseorang tidak semata-mata ditentukan oleh adanya faktor sosial bahkan dapat dikatakan bahwa faktor sosial dapat menentukan tingkat ekonomi seseorang dan juga sebaliknya faktor ekonomi dapat pula menentukan status sosial seseorang. Sehubungan dengan pendapat di atas, Gani (1984 : 152) berpendapat bahwa inti pembangunan sosial ekonomi masyarakat meliputu empat hal, yaitu :
1) Upaya tingkat pendidikan masyarakat;2) Peningkatan derajat kesehatan; 3) Perumahan masyarakat; 4) Peningkatan pendapatan masyarakat.

Dari pengertian diatas maka tingkat kesejatraan tertentu dari individu maupun keluarga dicapai, apabila telah terpenuhi kebutuhan dasarnya. Kesejatraan pada umumnya disamakan dengan taraf hidup, yang berarti pula penentuan kebutuhan konsumsi secara nyata dan ini bisa dicapai usaha memperbesar produksi yang dapat meningkatkan pendapatan masyarakat dan yang mempercepat proses pertumbuhan ekonomi

Makna pendidikan secara sederhana adalah usaha manusia untuk membina kepribadiannya sesuai dengan nilai-nilai kebudayaan yang ada dalam masyarakat, dengan demikian maka bagaimanapun sederhananya peradaban suatu masyarakat, maka didalamnya t erjadi suatu proses pendidikan.

Pendidikan merupakan proses pemberdayaan peserta didik sebagai subyek sekaligus obyek dalam membangun kehidupan yang baik. Mengingat pendidikan sangat berperan dalam meningkatkan kualitas sumber daya manusia, maka pembangunan dibidang pendidikan meliputi pembangunan pendidikan secara formal maupun non formal. Titik berat pendidikan formal adalah peningkatan mutu pendidikan dan perluasan pendidikan besar. selai itu, ditingkatkan pula kesempatan belajar pada jenjang pendidikan yang lebih tinggi.Untuk mencapai sasaran tersebut, berbagai upaya yang dilakukan pemerintah dengan meningkatkan sarana dan prasarana pendidikan, perbaikan kurikulum dengan harapan tingkat pendidikan semakin membaik dan tentunya akan berpengaruh pada tingkat kesejatraan penduduk

$\begin{array}{lrr} & \text { Indikator Penilaian } & \text { Kondisi } \\ \text { Sosial Ekonomi MasyarakatDalam } \\ \text { melakukan pengamatan ran serta } \\ \text { memberikan penilaian mengenai }\end{array}$


didasarkan pada indikator-indikator penelitian yang sifatnya fisik dan non fisik sehingga menggambarkan kondisi yang sesungguhnya (Badan Pusat Statistik, 2001).

Indikator Keluarga Sejahtera Menurut BPS tahun 2005.Berdasarkan indikator menurut Badan Pusat Statistik tahun 2005 untuk mengetahui tingkat kesejatraan masyarakat transmigran di Desa Wapae Jaya Kecamatan Tiworo
Tengah Kabupaten Muna Barat menggunakan 8 pendekatan yaitu Pendidikan, pendapatan, keadaan tempat tinggal, fasilitas tempat tinggal, kesehatan anggota keluarga, kemudahan mendapatkan pelayanan kesehatan, konsumsi atau pengeluaran rumah tangga dan kemudahan memasukan anak ke jenjang pendidikan yang lebih tinggi.

Tabel 2.2. Indikator Keluarga Sejahtera Menurut BPS Tahun 2005

\begin{tabular}{ccc}
\hline No & Indikator Kesejatraan & Kriteria \\
\hline 1 & Pendidikan & Baik (perguruan tinggi) \\
& & Sedang (SMP dan SMA) \\
& Rendah (SD) \\
\hline 2 & Pendapatan & Baik (Rp 10.000.000) \\
& & Sedang(Rp5.000.000Rp10.000.000) \\
& Rendah (<Rp5.000.000) \\
\hline 3 & Keadaan tempat tinggal & Baik (Permanen) \\
& & Sedang (Semi Permanen) \\
& & Rendah (Non Permanen) \\
\hline 4 & Fasilitas tempat tinggal & Baik \\
& & Sedang \\
& & Rendah \\
\hline 5 & Kesehatan anggota keluarga & Baik \\
& & Sedang \\
& & Rendah \\
\hline 6 & Kemudahan mendapatkan & Baik \\
& pelayanan kesehatan & Sedang \\
& & Rendah \\
\hline 7 & Konsumsi pengeluaran rumah & Baik $($ Rp 5.000.000) \\
& tangga & Rendah (<Rp1.000.000) \\
\hline 8 & Kemudahan memasukan anak & Baik \\
& kejenjang pendidikan lebih & Sedang \\
& tinggi & Rendah \\
\hline
\end{tabular}

Sumber : Badan Pusat Statistk Tahun 2005

\section{METODE PENELITIAN}

Penelitian ini berlokasi di Desa Wapae Jaya Kecamatan Tiworo Tengah Kabupaten Muna Barat, penentuan lokasi ini berdasarkan atas pertimbangan bahwa di Desa Wapae Jaya terdapat masyarakat transmigran etnik Bali. Adapun waktu penelitian di laksanakan pada tanggal 10 sampai 30 Januari 2017 Populasi dalam penelitian ini adalah seluruh kepala keluarga (KK) masyarakat transmigran etnik Bali yang ada di Desa Wapae Jaya Kecamatan Tiworo Tengah Kabupaten Muna Barat sebanyak 420 kepala keluarga.Penentuan sampel dalam penelitian ini adalah semua kepala keluarga di Desa Wapae Jaya yaitu sebanyak 420 KKJenis dan Sumber Datajenis DataJenis data primer terdiri dari : pendapatan, pendidikan, perumahan dan kesehatan Jenis data sekunder terdiri 
dari: keadaan alam, jumlah penduduk, potensi ekonomi desa, sarana dan prasarana sosial ekonom.Sumber Data

Data primer bersumber dari hasil penelitian lapangan pada 45 orang responden melalui kuisioner dan wawancara. Sedangkan data sekunder berasal dari kantor desa Wapae Jaya. Variabel yang Diteliti,Variable sosial ekonomi ; 1) Pendidikan; 2) Perumahan; 3) Kesehatan.

Tehnik PengumpulanData, dalam usaha untuk pengumpulan data dalam penelitian ini, penulis menggunakan cara sebagai berikut : 1. Observasi, Observasi dalam penelitian ini yaitu melakukan kunjungan dan pengamatan pada lokasi penelitian. 2. Angket (kuisioner)Angket (kuisioner) yaitu sutau tehnik dengan menyebar kuisioner untuk pengumpulan data dengan memberikan atau menyebarkan daftar pertanyaan kepada responden dengan harapan memberikan respon atas daftar pertanyaan tersebut; 1) Dokumentasi,dokumentasi yaitu data potensi desa dari kantor desa Wapae Jaya serta instansi yang terkait seperti data kependudukan dan data kondisi sosial ekonomi penduduk;2) Wawancara

wawancara atau Interview yaitu percakapan antara dua orang atau lebih dan berlangsung anatara narasumber dan pewawancara, tujuannya yaitu untuk mendapatkan informasi yang tepat dari narasumber yang terpercaya. Adapun responden yang diwawancarai dalam penelitian ini adalah sebanyak 15 responden yang merupakan tokoh-tokoh dalam masyarakat.

Metode Analis DataTeknik analisis data dalam penelitian ini adalah teknik analisis secara deskriptif melalui persentase \% yakni untuk mendapatkan gambaran secara jelas mengenai kondisi sisoal ekonomi masyarakat transmigran etnik Bali di Desa Wapae Jaya Kecamatan Toworo Tengah Kabupaten Muna Barat. Adapun teknik analisis data antara lain: 1.Membuat tabel distribusi frekuensi, hal ini dilakukan agar hasil penelitian mudah dipahami, 2. Dari tabel distribusi frekuensi maka ditentukan

\section{HASIL PENELITIAN}

Tingkat pendidikan adalah jenjang pendidikan formal yang telah diselesaikan sampai mendapatkan keterangan lulus. Tingkat pendidikan turut mempengaruhi cara berpikir dan bertindak seseorang. Pendidikan yang cukup tinggi mengakibatkan seseoarang lebih dinamis dalam mengambil keputusan ketika melakukan kegiatannya, adapun tingkat pendidikan yang dimaksud dalam penelitian ini adalah jenjang pendidikan formal yang telah dilalui oleh responden. Berdasarkan hasil penelitian dilapangan menunjukan bahwa tingkat pendidikan persentase setiap butur angket dengan rumus yang dikemukakan oleh Mukhtar dan Erna, 2000; 3. Dari tabel distribusi frekuensi maka ditentukan persentase setiap butir angket dengan rumus sebagai berikut:

$\mathrm{P}=\frac{F}{N} \mathrm{X} 100 \%$

Keterangan:

$\mathrm{P}=$ Persentase nilai yang sedang dicari

$\mathrm{F}=$ Frekuensi data yang diperoleh setiap option

$\mathrm{N}$ = Jumlah sampel yang diolah

responden masih dikategorikan rendah. Hal ini dapat dilihat dari sebanyak 420 responden, 64 responden diantaranya tidak tamat SD dan sebanyak 256 responden atau sebesar $62,95 \%$ rata-rata mempunyai pendidikan formal yang ditamatkan hanya pada tingkat SD. Tingkat pendidikan yang demikian ini dapat menunjukan tingkat pemahaman masyarakat dari berbagai bidang kegiatan pembangunan masih sangat kurang.

\begin{tabular}{ccc}
\multicolumn{2}{c}{ Rendahnya } & \multicolumn{2}{c}{ pendidikan } \\
responden & dalam & penelitian ini \\
disebabkan & oleh & kurangnaya
\end{tabular}


pemahaman mereka dalam dunia pendidikan sehingga masyarakat transmigran etnik Bali lebih mementingkan mencari uang seta membantu orang tua mereka berkebun dari pada bersekolah"berdasarkan hasil wawancara melalui informan Bapak Komang Redita mengatakan bahwa dia hanyalah tamatan SD dan tidak melanjutkan skolahnya karena faktor keadaan ekonomi dan kedua orang tuanya meninggal dunia,(wawancara, kamis 12 Januari 2017)."

Kondisi kesehatan meliputi kondisi fisisk, mental dan lingkungan suatu masyarakat jelas terikat dengan keberadaan pola hidup yang ditampilkan oleh masyarakat yang bersangkutan, kesehatan adalah salah satu unsur penting dalam hidup, karena dengan kondisi kesehatan yang baik maka aktifitas untuk menjalankan kehidupan sehari-hari dalam mencari nafkah akan berjalan dengan lancar. Sebaliknya seseorang dalam kondisi yang kurang sehat maka aktifitas sehari hari akan terganggu.

Keluarga dengan status sosial yang tinggi akan berobat pada tempat yang mahal dan tidak khawatir dengan biaya yang tinggi. Responden hanya akan berobat kepuskesmas apabila penyakit yang diderita kompleks atau parah. Kebiasaan yang terjadi adalah seringnya membeli obat dikios tanpa resep dokter. Berdasarkan wawancara dengan mereka yang akan berobat kepuskesmas, bidan atau tenaga medis apabila ada yang sakit parah atau luka parah. Biasanya penyakit yang sering menyerang mereka adalah demam, flu, batuk-batuk, sakit pinggang dan darah tinggi.

Status Kepemilikan Rumah merupakan salah satu bagi kehidupan manusia dimana merupakan kebutuhan dasar yang harus dipenuhi oleh makhluk hidup yang berpikir, karena fungsi bagi masyarakat tidak hanya sekedar pemenuhan kebutuhan tempat tinggal atau tempat berlindung saja akan tetapi diselaraskan dengan kebutuhan lain seperti keamanan dan kenyamanan dalam lingkungan keluarga maupun masyarakat sekitarnya.Berdasarkan hasil penelitian dilapangan menunjukan bahwa status kepemilikian rumah yang ditempati oleh responden adalah milik sendiri. Untuk lebih jelasnya status rumah yang ditempati responden, dapat dilihat pada tebel sebagai berikut:

Tabel 4.14 status kepemilikan rumah responden

\begin{tabular}{cccccccc}
\hline No & $\begin{array}{c}\text { Kepemilikan } \\
\text { rumah }\end{array}$ & \multicolumn{7}{c}{ Mata Pencaharian } \\
\cline { 3 - 8 } & Montir & Petani & Peternak & PNS & Jumlah & \% \\
\hline 1 & Milik sendiri & 25 & 233 & 152 & 10 & 420 & 100 \\
\hline 2 & Menumpang & - & - & - & & & - \\
\hline 3 & Kontrak/sewa & - & - & - & - & & - \\
\hline & Jumlah & $\mathbf{9}$ & $\mathbf{2 3 3}$ & $\mathbf{1 5 2}$ & $\mathbf{1 0}$ & $\mathbf{4 2 0}$ & $\mathbf{1 0 0}$ \\
\hline
\end{tabular}

Sumber: data diolah 2017 
dengan pendapatan pekerjaan pokok yang ditekuni oleh mereka untuk memenuhi kebutuhan hidup keluarga.

Menunjukan bahwa pendapatan pokok masyarakat transmigran etnik Bali di Desa Wapae Jaya yaitu Rp $<1.500 .000$ sebanyak 5 responden atau sebesar 1,19\%, kemudian dengan pendapatan $\mathrm{Rp} \quad 1.500 .000$ sampai Rp2.500.000 sebanyak 164 responden atau sebesar 39,04\%, kemudian untuk pendapatan Rp2.510.000 sampai Rp3.500.000 sebanyak 230 responden atau sebesar 54,76\%, sedangkan pendapatan >Rp3.500.000 sebanyak 21 responden atau sebesar 5\%,
Berdasarkan pendapatan dari segi pendapatan pokok yang diterima responden dapat dikategorikan sedang dimana sebanyak 230 responden memiliki pendapatan antara Rp 2.510.000 sampai $\quad \mathrm{Rp}$ 3.500.0008.700.000 dan PNS memiliki pendapatan rata-rata sebesara $\mathrm{Rp}$ 2.800.000.

Selain pendapatan pokok masyarakat transmigran etnik Bali di Desa Wapae Jaya juga memiliki pekerjaan sampingan. Untuk memperoleh gambaran lebih jelas dapat dilihat pada tabel berikut:

Tabel 4.25. Pekerjaan Sampingan Responden

\begin{tabular}{|c|c|c|c|c|c|c|c|}
\hline \multirow[t]{2}{*}{ No } & \multirow{2}{*}{$\begin{array}{c}\text { Pekerjaan } \\
\text { Sampingan }\end{array}$} & \multicolumn{6}{|c|}{ Mata Pencaharian Responden } \\
\hline & & Montir & Petani & Peternak & PNS & Jumlah & $\%$ \\
\hline 1 & Kios & 3 & 6 & 1 & - & 10 & 34,48 \\
\hline 2 & $\begin{array}{c}\text { Penjual Bahan } \\
\text { Bangunan }\end{array}$ & 2 & - & 1 & 1 & 4 & 13,79 \\
\hline 3 & $\begin{array}{c}\text { Penjual Bensin } \\
\text { Enceran }\end{array}$ & 8 & 3 & 2 & - & 13 & 44,82 \\
\hline 4 & Rumah Maka & - & - & 1 & 1 & 2 & 6,89 \\
\hline & Jumlah & 13 & 9 & 5 & 2 & 29 & 100 \\
\hline
\end{tabular}

Sumber : Data diolah 2017

Berdasarkan tabel diatas menunjukan bahwa responden yang mempunyai pekerjaan sampingan kios sebanyak 10 orang atau sebesar $34,48 \%$, kemudian yang mempunyai pekerjaan sampingan menjual bahan bangunan sebanyak 4 responden atau sebesar $13,79 \%$, kemudia yang mempunyai pekerjaan sampingan penjual bensin enceran sebanyak 13 responden atau sebesar $44,82 \%$, dan yang mempunyai

Berdasarkan hasil analisis kondisi sosial ekonomi menunjukan bahwa kondisi sosial ekonomi masyarakat transmigran etnik Bali di Desa Wapae Jaya menunjukan suatu kondisi sosial ekonomi tingkat sedang. $\mathrm{Hal}$ ini berdasarkan pada indikator yang ada didalamnya seperti pendidikan, pekerjaan sampingan rumah makan yaitu sebanyak 2 responden atau sebesar $6,89 \%$. Sedangkan responden yang tidak melakukan usaha sampingan untuk menambah penghasilan keluaraga dengan alasan sudah cukup untuk memenuhi kebutuhan dan ada juga yang berasalasan tdk ada waktu untuk mengurus pekerjaan sampingan.

\section{PEMBAHASAN}

perumahan, kesehatan dan pendapatan. Dimana dari keempat indiktor ini yaitu dilihat dari pendidikan masyarakat transmigran etnik Bali di Desa Wapae Jaya bahwa sebagian besar responden telah menamatkan pendidikan formalnya dan ini dapat meningkatkan taraf intelektualitas. Selain dapat 
meningkatkan taraf intelektualitas dapat pula masyarakat berpartisipasi terhadap pembangun. Akan tetapi apabila dilihat berdasarkan indikator penilaian kondisi pendidikan masyarakat transmigran etnik Bali di Desa Wapae Jaya dapat dikaterorikan masih rendah. Hal ini dapat dilihat dari 420 responden 256 responden atau sebesar $62,95 \%$ asumsi pendidikan formal yang ditamatakan rata-rata hanya pendidikan formal tingkat SD.

Dilihat dari kondisi kesehatan responden masyarakat transmigran etnik Bali di Desa Wapae Jaya berada pada kriteria sedang, dimana tingkat kesadaran masyarakat transmigran etnik Bali di Desa Wapae Jaya akan kesehatan sangat tinggi dimana mereka sangat memperhatikan kebersihan lingkungan mereka. Selain itu juga, ketika mereka terserang penyakit mereka segera memeriksakan kesehatan mereka kepuskesmas setempat atau rumah sakit dengan alasan puskesmas atau rumah sakit pelayanannya yang baik dan cara pengobatan yang praktis, masyarakat transmigran etnik Bali di Desa Wapae Jaya sudah tidak lagi pergi berobat kepada dukun.

Kemudian dilihat dari kondisi perumahan responden masyarakat transmigran etnik Bali di Desa Wapae Jaya dimana semua responden telah memiliki rumah sendiri. Dalam hal ini semua responden sudah tidak ada yang kontrak atau menumpang sama keluarga, sehingga kondisi perumahan responden masyarakat transmigran etnik Bali di Desa Wapae Jaya berada pada kriterian yang tinggi. Hal ini juga ditunjukan dengan yang ada didalamnya seperti status kepemilikan rumah, jenis lantai rumah, dinding rumah, atap rumah, plafon, sumber penerangan, sember air bersih dan kepemilikan MCK.
Dilihat dari kondisi pendapatan responden masyarakat transmigran etnik Bali yang ada di Desa Wapae Jaya meunjukan bahwa semua responden memiliki perjaan pokok dan ada juga sebagai responden memiliki pekerjaan sampingan. Responden yang memilki pekerjaan sampingan dengan alasan untuk menambah penghasilan keluarga, sedangkan responden yang tidak memiliki pekerjaan sampingan dengan alasan tidak memiliki waktu untuk mengurus pekerjaan sampingan karena pekerjaan pokok yang banyak. Pendapatan responden setiap bulannya rata-rata berkisar antara $\mathrm{Rp} 2.500 .000$ sampai $\mathrm{Rp} 3.500 .000$. didasarkan pada indikator penilaian tersebut maka pendapatan berada pada kriteria sedang.Berdasarkan indikator menurut Badan Pusat Statistik tahun 2005 untuk mengetahui tingkat kesejatraan masyarakat transmigran di Desa Wapae Jaya Kecamatan Tiworo Tengah Kabupaten Muna Barat menggunakan 8 pendekatan yaitu Pendidikan, pendapatan, keadaan tempat tinggal, fasilitas tempat tinggal, kesehatan anggota keluarga, kemudahan mendapatkan pelayanan kesehatan, konsumsi atau pengeluaran rumah tangga dan kemudahan memasukan anak ke jenjang pendidikan yang lebih tinggi.

Berdasarkanindikator keluarga sejahtera menurut BPS Tahun 2005 menunjukan bahwa kondisi sosial ekonomi masyarakat transmigran etnik Bali di Desa Wapae Jaya berada pada tingkat keluarga sejahtera sedang. Hal ini dapat dilihat dari pendidikannya dimana dari 420 responden 256 responden atau sebesar $62,95 \%$ pendidikan formal yang ditamatkan hanya pada tingkat SD. Hal ini menunjukan bahwa pendidikan responden masih rendah, kemudian dilihat dari pendapatan responden dimana sebanyak 420 respoden 230 responden atau sebesar $54,76 \%$ pendapatan rata-rata per bulan berkisar 
antara $\quad \mathrm{Rp} \quad 2.500 .000$ sampai Rp 3.500.000 dimana menurut BPS 2005 tingkat pendapatan responden berada pada tingkat sedang. Kemudian dilihat dari keadaan tempat tinggal dimana dari 420 responden sebanyak 258 responden atau sebesar $61,42 \%$ responden memiliki rumah permanen sehingga dikategorikan baik selain itu didukung juga dengan luas banguna rumah, jenis lantai, jenis dinding,sumber penerangan dan kepemilikan MCK. Kemudian dilihat dari fasilitas tempat tinggal responden berada pada tingkat sedang, hal ini dapat dilihat perabot rumah, jenis kendaraan yang digunakan. Kemudian dilihat dari keadaan kesehatan anggota keluarga dimana dalam 6 bulan terahir responden memiliki anggota keluarga yang sakit dimana anak-anak mereka menderita penyakit flu dan batuk-batuk akibat cuaca yang tidak menentu, selain itu juga dalam 6 bulan terahir responden juga menderita penyakit seperti demam, sakit pinggang, rematik dan asam urat akan tetapi respoden segera memeriksaan kesehatan dipuskesmas, bidan dan tenaga medis lainnya sehingga untuk kesehatan respopnden berada pada tingkat sedang, kemudian dilihat dari kemudahan mendapatkan pelayanan kesehatan responden berada pada tingkat sedang hal ini dapat dilihat dimana responden selalu memeriksakan kesehatannya dipuskesmas atau rumah sakit dengan alasan puskesmas atau rumah sakit pelayananya bagus dan praktis.

Kemudian dilihat dari konsumsi pengeluaran rumah tangga dimana dari 420 responden 211 responden atau sebesar $50,23 \%$ pengeluaran rata-rata untuk kebutuhan perbulan berkisar antara Rp1.150.000 sampai Rp1.500.000, sehingga untuk konsumsi pengeluaran rumah tangga berada pada tingkat sedang. Kemudian dilihat dari kemudahan memasukan anak kejenjang perguruan lebih tinggi berada pada kriteria yang baik dimana dapat dilihat pada tingkat pendidikan anak responden dimana terdapat 192 anak responden yang sementara melanjutkan perguruan tinggi diberbagai universitas sementara anak responden lain yang masih melanjutkan SD, SMP, SMA.

\section{KESIMPULAN}

Berdasarkan tabel indikator keluarga sejahtera menurut BPS Tahun 2005 menunjukan bahwa kondisi sosial ekonomi masyarakat transmigran etnik Bali di Desa Wapae Jaya berada pada tingkat keluarga sejahtera sedang. Hal ini dapat dilihat dari:1.Pendidikannya dimana dari 420 responden 256 responden diantaranya atau sebesar $62,95 \%$ pendidikan formal yang ditamatkan hanya pada tingkat SD. 2. Pendapatan rata-rata per bulan berkisar antara Rp 2.500.000 sampai Rp 3.500.000 dimana menurut BPS 2005 tingkat pendapatan responden berada pada tingkat sedang. 3.Keadaan tempat tinggal responden sebesar $61,42 \%$ responden memiliki rumah permanen sehingga dikategorikan tinggi selain itu didukung juga dengan luas banguna rumah, jenis lantai, jenis dinding,sumber penerangan dan kepemilikan MCK. 4.Fasilitas tempat tinggal responden berada pada tingkat sedang, hal ini dapat dilihat perabot rumah dan jenis kendaraan yang digunakan. 5.Kesehatan anggota keluarga dimana dalam 6 bulan terahir hanya sebesar $10 \%$ responden memiliki anggota keluarga yang sakit dimana anak-anak mereka menderita penyakit flu dan batuk-batuk akibat cuaca yang tidak menentu, sehingga untuk kesehatan respopnden berada pada tingkat sedang. 6 . Kemudahan mendapatkan pelayanan kesehatan responden berada pada tingkat sedang. 7. pengeluaran rumah tangga rata-rata perbulan berkisar antara Rp1.150.000 sampai Rp1.500.000, sehingga untuk konsumsi pengeluaran rumah tangga berada pada tingkat sedang. 
8.Kemudahan memasukan anak kejenjang perguruan lebih tinggi berada pada kriteria yang tinggi dimana terdapat 192 anak responden yang sementara melanjutkan perguruan tinggi diberbagai unuversitas di Indonesia.

Saran,Bagi masyarakat transmigran etnik Bali yang ada di Desa Wapae Jaya diharapkan agar tingkat pendapatannya ditingkatkan lagi sehingga dapat meningkatkan kondisi sosial ekonomi keluarga terutama pada tingkat pendidikan, kesehatan dan kondisi perumahan, Kepada pemerintah daerah, kiranya lebih memeperhatikan kondisi sosial ekonomi masyarakat transmigran yang ada di Desa Wapae Jaya Kecamatan Toworo Tengaha Kabupaten Muna Barat melalui bantuan pembinaan

\section{DAFTAR PUSTAKA}

Gani, A. 1984. Indikator Pembangunan Manusia dan Penduduk, Prisma NO 4.
Koenjaraningrat. 1974. Antropologi Sosial. Jakarta : UI Press.

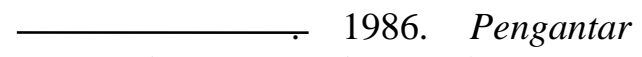
Ilmu Antropologi . Jakarta : CV Aksara Baru.

1985. Metodologi Penelitian Sosial. Jakarta : Gramedia.

Sulaeman B. Taneko, 1986. Konsep System Sosial dan System Sosial Indonesia.Jakarta : Fajar Agung

Sukirna,S. 1985. Pengantar Teori Makro Ekonomi . BPFE UI. Jakarta.

Syam. 1980. Pengantar Dasar-Dasar Pendidikan. Surabaya: Usaha Nasional.

Syani. 1984. Sosiologi Ekonomi. Bahasa Aksa. IBM.

UU RI No. 20 Tahun 2003. Tentang Sistem Pendidikan Nasional.

Winardi. 1982. Kamus Ekonomi. Alumni. Bandung 